\title{
BREEDING FOR DROUGHT TOLERANCE IN OIL PALM
}

\section{CORLEY, R H V*; RAO, V**; PALAT, $\mathrm{T}^{\ddagger}$ and PRAIWAN, $\mathrm{T}^{\ddagger}$}

\begin{abstract}
As the oil palm industry expands, drought tolerance will become increasingly important. In the breeding programme of Univanich Palm Oil PCL in Southern Thailand, progeny trials are duplicated with and without irrigation. This allows drought tolerance of progenies to be estimated, in terms of the reduction in yield caused by withholding irrigation. Correlations between irrigated and unirrigated progeny mean yields are low, and some pairs of trials show significant progeny $x$ irrigation interactions. Unirrigated yield is highly correlated with drought tolerance, but yield under irrigation tends to be negatively correlated with tolerance. Thus, selection in the absence of drought may produce material that is drought susceptible, and selection should be done under the conditions in which the material will be planted. We have not found a reliable indirect method for identifying drought tolerance, but the use of stomatal conductance as a selection criterion appears worth investigating further.
\end{abstract}

Keywords: Elaeis guineensis, irrigation, breeding values, yield, GxE interaction.

Date received: 12 April 2017; Sent for revision: 16 May 2017; Received in final form: 7 August 2017; Accepted: 12 September 2017.

\section{INTRODUCTION}

The oil palm (Elaeis guineensis Jacq.) is the highest yielding vegetable oil crop (Corley and Tinker, 2016), and to meet ever-increasing demand, production of palm oil has trebled over the last 20 years, mainly through increase in planted area. The earliest plantations were in parts of Malaysia and Indonesia with seasonally well-distributed rainfall, but the expansion of the oil palm industry has included extension into regions with a significant annual dry season. In Southern Thailand, for example, there is normally a three- to four-month dry season, which has been shown to reduce palm oil yields by $25 \%$ - 35\% (Palat et al., 2008). Demand for vegetable oil is expected to continue increasing, and the increase will probably be met largely by expansion of the oil

\footnotetext{
* Highlands, New Road, Great Barford, Bedford MK44 3LQ, United Kingdom. E-mail: herewardc@aol.com

** Lot $6729, \mathrm{Kg}$ Batu Satu, 43800 Dengkil, Selangor, Malaysia.

‡ Univanich Palm Oil Public Co. Ltd, Krabi, Thailand.
}

palm industry (Corley, 2009), so drought tolerance is likely to become increasingly important in future.

Drought affects oil palm yield by reducing fruit bunch number, through changes in the ratio of female to male inflorescences (Corley and Hong, 1982) and inflorescence abortion rate (Desmarest, 1967). These changes occur up to two years before fruit harvest. Thus, there may be discrepancies between current photosynthetic production and demand from developing bunches. While gas exchange is affected by current conditions, bunch demand depends on drought effects in previous years. Trunk carbohydrate reserves provide a buffer between the two (Legros et al., 2009).

Several authors have described variation in physiological responses of oil palms to drought (Da Silva et al., 1984; Smith, 1993; Lamade et al., 1998; Suresh et al., 2008; 2010; 2012; Rivera Méndez et al., 2012; Silva et al., 2015; 2017), or physiological and morphological differences between 'drought susceptible' and 'drought tolerant' material (Cornaire et al., 1989; 1994). However, the criteria for defining drought tolerance are not always clear. 
In areas such as Benin, with a long and severe dry season, death of young palms is common, and drought tolerance has been defined simply in terms of survival (Houssou et al., 1989). Elsewhere a regular dry season may depress yields without being so severe as to kill palms; in such environments the effect on yield provides a measure of drought tolerance with practical relevance. Nodichao et al. (2011) defined drought tolerance in terms of yield in a dry environment, with a tolerant cross having larger yield than a susceptible cross. However, high yield in a dry environment might arise in two ways: the palms might be drought tolerant, with little effect of drought on yield, or they might be susceptible, but with a very high yield potential in the absence of drought, such that even the reduced yield under drought remains good (Blum, 2005).

Oil palm planting material is produced by crossing thick-shelled dura palms with shell-less (but commonly female-sterile) pisifera palms, to produce the tenera fruit form. This has thin shell, more oil-bearing mesocarp and larger oil yield than the dura (Corley and Tinker, 2016). A single pisifera can yield sufficient pollen to produce several million seed per year, so it is important to identify the best pisiferas by progeny testing. A single dura will only produce about 10000 seed per year, but the best duras can be cloned to increase production (Veerappan et al., 2000). In the Univanich breeding programme described here, progeny trials have been duplicated in irrigated and unirrigated conditions, to identify differences in the effect of drought. The aim is to select parents which give drought tolerant progenies, in which the yield depression caused by drought is minimised. Yield with irrigation $(Y p)$ gives an indication of yield potential, while the relative difference between $Y p$ and yield without irrigation $\left(Y_{S}\right)$ gives a measure of drought susceptibility.

\section{MATERIAL AND METHODS}

Trials

All trials were planted by Univanich Palm Oil PCL in Southern Thailand (approximately $8^{\circ} 30^{\prime} \mathrm{N}$, $\left.98^{\circ} 50^{\prime} \mathrm{E}\right)$. There is normally a three- to four-month dry season in this area, with potential annual water deficit (rainfall minus pan evaporation) averaging $316 \mathrm{~mm}$ over the period 2006 to 2015, and ranging from 79 to $650 \mathrm{~mm}$ in individual years.

Seven pairs of trials are described here, with identical sets of progenies inirrigated and unirrigated conditions. The trials of each pair were planted at the same time, and were typically about $4 \mathrm{~km}$ apart. Drip irrigation was used, as described by Palat et al. (2008). Details of the trials are given in Table 1. All trials were in randomised block designs. For each trial, data from all fully-replicated progenies were considered; some trials also included additional progenies which were not fully replicated, or for which data records were incomplete. Both trials in each pair received the same standard fertiliser dressings.

\section{Records and Statistical Analysis}

Yield of fresh fruit bunches (FFB) was recorded by weighing every bunch immediately after harvest. The mean bunch numbers and weights given here are averages of annual means over the years of recording. Although pairs of trials were the same

TABLE 1. DETAILS OF IRRIGATED AND UNIRRIGATED PROGENY TRIALS

\begin{tabular}{|c|c|c|c|c|c|c|c|c|c|c|}
\hline \multirow[t]{2}{*}{ Trials $^{a}$} & \multirow{2}{*}{$\begin{array}{c}\text { Year } \\
\text { planted }\end{array}$} & \multirow{2}{*}{$\begin{array}{c}\text { Density } \\
\left(\text { palms ha }{ }^{-1}\right)\end{array}$} & \multirow{2}{*}{$\begin{array}{l}\text { Years } \\
\text { recorded }\end{array}$} & \multirow{2}{*}{$\begin{array}{l}\text { No. of } \\
\text { blocks }\end{array}$} & \multirow{2}{*}{$\begin{array}{l}\text { Crosses } \\
\text { per trial }\end{array}$} & \multicolumn{2}{|c|}{ No. of parents } & \multirow{2}{*}{$\begin{array}{l}\text { Palms } \\
\text { per/plot }\end{array}$} & \multirow{2}{*}{$\begin{array}{l}\text { Bunches } \\
\text { analysed }^{\text {b }}\end{array}$} & \multirow{2}{*}{$\begin{array}{l}\text { Other } \\
\text { crosses }^{c}\end{array}$} \\
\hline & & & & & & Dura & Pisifera & & & \\
\hline UPT05/1i & 2005 & 150 & 5.5 & 2 & 39 & 24 & 18 & 20 & 53 & 1 \\
\hline UPT05/2 & 2005 & 143 & 5 & 2 & 39 & 24 & 18 & 12 & 35 & 1 \\
\hline UPT05/3i & 2005 & 143 & 7 & 2 & 30 & 25 & 18 & 14 & 16 & - \\
\hline UPT05/4 & 2005 & 143 & 7 & 2 & 30 & 25 & 18 & 14 & 17 & - \\
\hline UPT06/3i & 2006 & 150 & 4.5 & 3 & 13 & 10 & 7 & 16 & 51 & 1 \\
\hline UPT06/4 & 2006 & 150 & 4 & 3 & 13 & 10 & 7 & 16 & 25 & - \\
\hline UPT06/5i & 2006 & 150 & 4.4 & 3 & 29 & 22 & 13 & 16 & 52 & 7 \\
\hline UPT06/ 6 & 2006 & 150 & 4 & 3 & 29 & 22 & 13 & 16 & 38 & 7 \\
\hline UPT07/2i & 2007 & 143 & 3.4 & 3 & 18 & 14 & 8 & 16 & 32 & 25 \\
\hline UPT07/4 & 2007 & 143 & 3.4 & 3 & 18 & 14 & 8 & 16 & 22 & 25 \\
\hline UPT10/1i & 2010 & 143 & 3.3 & 3 & 11 & 10 & 9 & 16 & 17 & - \\
\hline UPT10/3 & 2010 & 143 & 3.2 & 3 & 11 & 10 & 9 & 16 & 14 & - \\
\hline UPT10/2i & 2010 & 143 & 3.3 & 3 & 24 & 18 & 14 & 16 & 15 & 2 \\
\hline UPT10/4 & 2010 & 143 & 3.2 & 3 & 24 & 18 & 14 & 16 & 16 & 2 \\
\hline
\end{tabular}


age, irrigated trials generally started yielding at a younger age than unirrigated trials, so were recorded for up to six months longer. For extraneous reasons, recording was interrupted in some trials; Table 1 shows the total number of years over which recording was done. Oil content of a random sample of bunches from each plot was determined by the standard NIFOR method (Blaak et al., 1963; Rao et al., 1983). Sampling was concentrated in the wet season. Vegetative growth was measured using standard methods (Corley et al., 1971; Breure and Verdooren, 1995). Leaf dry weight was estimated from petiole cross-section as described by Corley et al. (1971). Stomatal conductance was measured in one pair of trials in 2013, using a Delta-T AP4 porometer. One reading per palm was taken on leaf 17 , on three separate occasions during the 2013 dry season; all readings were averaged to give plot means.

Variation in each pair of trials was partitioned into progeny (genotype), site and progeny $x$ site (GxE) interaction components, tested against pooled error. We assumed that differences between sites represented differences due to irrigation, but soil differences might also have contributed. Correlations between means for progenies with and without irrigation gave another indication of GxE interaction.

Drought tolerance or susceptibility was assessed from means for each cross in terms of the reduction in yield caused by the lack of irrigation, expressed as a percentage of irrigated yield:

$$
100(Y p-Y s) / Y p
$$

We assumed that expressing the yield loss relative to irrigated yield would give a measure of drought tolerance independent of actual yield, so differences in average yield between trials due to palm age could be disregarded. By combining results for all the trials, 152 progenies linked through common parents were identified, to allow a 'males $x$ females' analysis of variance including 56 dura and 58 pisifera parents. Least square means from this analysis gave estimates of additive breeding values for the degree of drought tolerance conferred by individual parents.

TABLE 2. EFFECT OF IRRIGATION AND PROGENY $x$ IRRIGATION ANALYSIS - YIELD AND YIELD COMPONENTS

\begin{tabular}{|c|c|c|c|c|c|c|c|c|}
\hline \multirow[b]{2}{*}{ Trials } & \multirow[b]{2}{*}{ Irrigated } & \multirow[b]{2}{*}{ Dry } & \multicolumn{3}{|c|}{ Drought loss (\% irrig.) ${ }^{a}$} & \multicolumn{3}{|c|}{ Variance ratios for } \\
\hline & & & Mean & $\begin{array}{l}\text { Best } \\
\text { cross }\end{array}$ & $\begin{array}{l}\text { Worst } \\
\text { cross }\end{array}$ & Progenies & Irrigation & $\begin{array}{c}\text { Progeny } \\
\text { x irrig. }\end{array}$ \\
\hline \multicolumn{9}{|l|}{ FFB yield $\left(\mathrm{t} \mathrm{ha}^{-1} \mathrm{yr}^{-1}\right)$} \\
\hline UPT05/1i and 05/2 & 27.2 & 23.1 & 15 & -6 & 31 & $0.90 \mathrm{~ns}$ & $81.8^{* * *}$ & $0.85 \mathrm{~ns}$ \\
\hline UPT05/3i and 05/4 & 23.3 & 20.6 & 10 & -22 & 42 & 1.97 * & $26.3^{* * *}$ & $1.46 \mathrm{~ns}$ \\
\hline UPT06/3i and 06/4 & 25.9 & 20.9 & 19 & 7 & 35 & $2.14 \mathrm{~ns}$ & $93.4^{* * *}$ & $1.26 \mathrm{~ns}$ \\
\hline UPT06/5i and 06/6 & 26.6 & 21.1 & 20 & 7 & 33 & $2.39 * *$ & $239.0^{* * *}$ & $5.52 * * *$ \\
\hline UPT07 / $2 \mathrm{i}$ and $07 / 4$ & 18.3 & 15.4 & 15 & -9 & 52 & $2.53^{* *}$ & $45.8^{* * *}$ & $2.73^{* *}$ \\
\hline UPT10/1i and 10/3 & 13.0 & 10.9 & 16 & 4 & 31 & $1.60 \mathrm{~ns}$ & $22.8^{* * *}$ & $0.60 \mathrm{~ns}$ \\
\hline UPT10/2i and 10/4 & 12.8 & 8.5 & 34 & 22 & 52 & $1.51 \mathrm{~ns}$ & $240.1 * * *$ & $0.49 \mathrm{~ns}$ \\
\hline \multicolumn{9}{|l|}{ Bunch No. palm ${ }^{-1} \mathrm{yr}^{-1}$} \\
\hline UPT05/ $1 \mathrm{i}$ and $05 / 2$ & 18.7 & 16.4 & 13 & -1 & 24 & $6.36 * * *$ & $92.8^{* * *}$ & $0.97 \mathrm{~ns}$ \\
\hline UPT05/3i and 05/4 & 14.4 & 13.2 & 7 & -22 & 29 & $3.03 * * *$ & $15.9^{* * *}$ & $1.19 \mathrm{~ns}$ \\
\hline UPT06/3i and 06/4 & 18.4 & 15.3 & 17 & 2 & 30 & $4.47^{* *}$ & $91.0^{* * *}$ & $1.76 \mathrm{~ns}$ \\
\hline UPT06/5i and 06/ 6 & 20.6 & 16.7 & 19 & 6 & 31 & $9.20 * * *$ & $234.1^{* * *}$ & $1.33 \mathrm{~ns}$ \\
\hline UPT07 / $2 \mathrm{i}$ and $07 / 4$ & 15.9 & 12.8 & 18 & 6 & 55 & $7.68 * * *$ & $94.5 * * *$ & $3.63 * * *$ \\
\hline UPT10/1i and 10/3 & 12.4 & 10.9 & 12 & -2 & 26 & $1.46 \mathrm{~ns}$ & $12.3^{* *}$ & $0.55 \mathrm{~ns}$ \\
\hline UPT10/2i and 10/4 & 12.6 & 9.4 & 25 & 10 & 48 & $2.63^{* *}$ & $125.6^{* * *}$ & $0.65 \mathrm{~ns}$ \\
\hline \multicolumn{9}{|l|}{ Mean bunch wt (kg) } \\
\hline UPT05/1i and 05/2 & 10.6 & 10.4 & 2 & -16 & 14 & $9.08^{* * *}$ & $3.13 \mathrm{~ns}$ & $1.18 \mathrm{~ns}$ \\
\hline UPT05/3i and 05/4 & 12.3 & 11.5 & 6 & -16 & 19 & $18.0^{* * *}$ & $87.6^{* * *}$ & $2.97^{* * *}$ \\
\hline UPT06/3i and 06/4 & 10.1 & 8.8 & 13 & 6 & 19 & $7.52 * * *$ & $134.4^{* * *}$ & $0.72 \mathrm{~ns}$ \\
\hline UPT06/5i and 06/6 & 9.4 & 8.5 & 10 & 2 & 18 & $16.71^{* * *}$ & $207.1^{* * *}$ & $0.93 \mathrm{~ns}$ \\
\hline UPT07 / $2 \mathrm{i}$ and 07 / 4 & 7.8 & 7.6 & 3 & -29 & 33 & $5.08 * * *$ & $2.54 \mathrm{~ns}$ & $3.46^{* * *}$ \\
\hline UPT10/1i and 10/3 & 7.6 & 7.4 & 3 & -2 & 12 & $3.05^{* *}$ & 4.64 * & $0.78 \mathrm{~ns}$ \\
\hline UPT10/2i and 10/4 & 7.5 & 6.8 & 10 & 1 & 21 & $3.34^{* *}$ & $172.1^{* * *}$ & 2.52 ** \\
\hline
\end{tabular}

Note: a Negative values indicate increase under drought.

${ }^{*} \mathrm{P}<0.05,{ }^{* *} \mathrm{P}<0.01,{ }^{* * *} \mathrm{P}<0.001$

FFB - fresh fruit bunch.

ns - not significant. 


\section{RESULTS}

Effects of irrigation/drought and results of the GxE analysis for yield and yield components in each trial are given in Table 2. Drought (lack of irrigation) had highly significant effects on FFB yield in all pairs of trials; the average reduction in yield compared to the irrigated trial was $18 \%$. FFB yield is known to be affected mainly through changes in bunch number (Palat et al., 2008), and there were significant effects of drought on bunch number in all pairs of trials, with an average reduction of $16 \%$. Mean bunch weight was also reduced, significantly in some trials, by an average of $7 \%$. There were significant differences in FFB yield among progenies in four pairs of trials, and a significant GxE interaction in

TABLE 3. EFFECT OF IRRIGATION AND PROGENY $x$ IRRIGATION ANALYSIS - VEGETATIVE GROWTH

\begin{tabular}{|c|c|c|c|c|c|c|c|c|}
\hline \multirow[b]{2}{*}{ Trials } & \multirow[b]{2}{*}{ Irrigated } & \multirow[b]{2}{*}{ Dry } & \multicolumn{3}{|c|}{$\begin{array}{l}\text { Decrease in dry trial } \\
\text { (as } \% \text { irrigated) }{ }^{a}\end{array}$} & \multicolumn{3}{|c|}{ Variance ratios for } \\
\hline & & & Mean & Best & $\begin{array}{l}\text { Worst } \\
\text { progeny }\end{array}$ & Progenies & Irrigation & $\begin{array}{c}\text { Progeny } \\
x \text { irrig. }\end{array}$ \\
\hline \multicolumn{9}{|l|}{ Palm height (m) } \\
\hline UPT05/1i and 05/2 & 3.10 & 2.73 & 12 & 2 & 24 & $9.98^{* * *}$ & $124.5^{* * *}$ & $2.16^{* *}$ \\
\hline UPT05/3i and 05/4 & 2.35 & 2.57 & -9 & -23 & 6 & $5.44 * * *$ & $47.6^{* * *}$ & $0.82 \mathrm{~ns}$ \\
\hline UPT06/3i and 06/4 & 3.33 & 2.92 & 12 & 4 & 17 & $3.55^{* *}$ & $146.7^{* * *}$ & $1.20 \mathrm{~ns}$ \\
\hline UPT06/5i and 06/6 & 3.29 & 2.99 & 9 & 0 & 15 & $9.81 * * *$ & $102.6^{* * *}$ & $0.71 \mathrm{~ns}$ \\
\hline UPT07 / $2 \mathrm{i}$ and $07 / 4$ & 1.54 & 1.49 & 3 & -9 & 17 & 2.03 * & 3.65 ns & $1.10 \mathrm{~ns}$ \\
\hline UPT10/1i and 10/3 & 0.59 & 0.52 & 13 & 4 & 28 & 3.06 ** & $28.7^{* * *}$ & $0.95 \mathrm{~ns}$ \\
\hline UPT10/2i and 10/4 & 0.51 & 0.44 & 13 & -4 & 30 & $5.28 * * *$ & $40.9^{* * *}$ & $0.99 \mathrm{~ns}$ \\
\hline \multicolumn{9}{|l|}{ Mean leaf area $\left(\mathrm{m}^{2}\right)$} \\
\hline UPT05/1i and 05/2 & 9.84 & 8.33 & 15 & -3 & 27 & $1.10 \mathrm{~ns}$ & $88.6^{* * *}$ & 2.21 ** \\
\hline UPT05/3i and 05/4 & 8.58 & 8.87 & -4 & -26 & 16 & $1.30 \mathrm{~ns}$ & $2.32 \mathrm{~ns}$ & $0.63 \mathrm{~ns}$ \\
\hline UPT06/3i and 06/4 & 8.58 & 9.42 & -10 & -16 & -4 & 2.24 * & $41.2^{* * *}$ & $0.58 \mathrm{~ns}$ \\
\hline UPT06/5i and 06/6 & 8.45 & 9.82 & -16 & -26 & -9 & 1.58 * & $638.8^{* * *}$ & $1.27 \mathrm{~ns}$ \\
\hline UPT07 / $2 \mathrm{i}$ and 07 / 4 & 6.53 & 7.37 & -13 & -24 & -2 & 1.83 * & $161.3^{* * *}$ & $1.56 \mathrm{~ns}$ \\
\hline UPT10/1i and 10/3 & 5.42 & 5.57 & -3 & -7 & 2 & $1.45 \mathrm{~ns}$ & 5.34 * & $0.54 \mathrm{~ns}$ \\
\hline UPT10/2i and 10/4 & 5.43 & 5.60 & -3 & -13 & 5 & $1.20 \mathrm{~ns}$ & $8.96 * *$ & $0.92 \mathrm{~ns}$ \\
\hline \multicolumn{9}{|c|}{ Petiole cross-section area $\left(\mathrm{cm}^{2}\right)$} \\
\hline UPT05/1i and 05/2 & 30.3 & 31.7 & -5 & -28 & 21 & $4.62 * * *$ & 10.29 ** & $3.43^{* * *}$ \\
\hline UPT05/3i and 05/4 & 29.3 & 28.9 & 2 & -41 & 18 & $11.81 * * *$ & $0.96 \mathrm{~ns}$ & $3.11 * * *$ \\
\hline UPT06/3i and 06/4 & 33.0 & 24.1 & 25 & 14 & 30 & $7.65 * * *$ & $518.1 * * *$ & 2.27 * \\
\hline UPT06/5i and 06/6 & 28.3 & 25.8 & 8 & -1 & 18 & $2.89^{* * *}$ & $64.0 * * *$ & $0.76 \mathrm{~ns}$ \\
\hline UPT07 / $2 \mathrm{i}$ and $07 / 4$ & 23.9 & 23.3 & 2 & -19 & 14 & $5.50 * * *$ & $1.80 \mathrm{~ns}$ & $1.57 \mathrm{~ns}$ \\
\hline UPT10/1i and 10/3 & 19.4 & 15.7 & 19 & 6 & 32 & $1.77 \mathrm{~ns}$ & 175.0 *** & 2.51 * \\
\hline UPT10/2i and 10/4 & 18.0 & 15.8 & 12 & 6 & 18 & $1.06 \mathrm{~ns}$ & $221.6^{* * *}$ & $0.71 \mathrm{~ns}$ \\
\hline \multicolumn{9}{|l|}{ Rachis length (m) } \\
\hline UPT05/1i and 05/2 & 6.23 & 6.04 & 3 & -7 & 14 & $4.69^{* * *}$ & $27.0 * * *$ & $3.84 * * *$ \\
\hline UPT05/3i and 05/4 & 5.41 & 5.73 & -6 & -23 & 3 & $2.78 * * *$ & $38.7 * * *$ & $1.11 \mathrm{~ns}$ \\
\hline UPT06/3i and 06/4 & 6.31 & 6.32 & 0 & -8 & 6 & $6.81 * * *$ & $0.26 \mathrm{~ns}$ & $3.61 * * *$ \\
\hline UPT06/5i and 06/6 & 6.27 & 6.21 & 1 & -1 & 5 & 2.30 ** & $9.67^{* *}$ & $0.97 \mathrm{~ns}$ \\
\hline UPT07 / $2 \mathrm{i}$ and $07 / 4$ & 5.36 & 5.45 & -2 & -7 & 6 & $4.41^{* * *}$ & 6.35 * & $1.42 \mathrm{~ns}$ \\
\hline UPT10/1i and 10/3 & 4.60 & 4.56 & 1 & -1 & 4 & $1.32 \mathrm{~ns}$ & $5.55 *$ & $0.74 \mathrm{~ns}$ \\
\hline UPT10/2i and 10/4 & 4.54 & 4.45 & 2 & -1 & 5 & $1.52 \mathrm{~ns}$ & $34.7^{* * *}$ & $1.14 \mathrm{~ns}$ \\
\hline \multicolumn{9}{|c|}{ Ratio of leaf area to leaf dry weight $\left(\mathrm{m}^{2} \mathrm{~kg}^{-1}\right)$} \\
\hline UPT05/1i and 05/2 & 3.00 & 2.44 & 18 & -8 & 36 & 1.57 * & $113.6^{* * *}$ & $1.10 \mathrm{~ns}$ \\
\hline UPT05/3i and 05/4 & 2.70 & 2.87 & -7 & -45 & 22 & 1.78 * & 6.0 * & $0.95 \mathrm{~ns}$ \\
\hline UPT06/3i and 06/4 & 2.42 & 3.46 & -44 & -57 & -18 & $1.57 \mathrm{~ns}$ & $377.6^{* * *}$ & $1.53 \mathrm{~ns}$ \\
\hline UPT06/5i and 06/6 & 2.78 & 3.47 & -25 & -41 & -12 & $3.29 * * *$ & $784.6^{* * *}$ & $1.52 \mathrm{~ns}$ \\
\hline UPT07 / $2 \mathrm{i}$ and $07 / 4$ & 2.49 & 2.87 & -15 & -29 & -2 & $4.30 * * *$ & $108.7^{* * *}$ & $0.96 \mathrm{~ns}$ \\
\hline UPT10/1i and 10/3 & 2.49 & 3.10 & -25 & -38 & -7 & $2.69 *$ & $138.3^{* * *}$ & $1.95 \mathrm{~ns}$ \\
\hline UPT10/2i and 10/4 & 2.66 & 3.09 & -16 & -26 & -8 & 1.74 * & 223.9 * & $0.93 \mathrm{~ns}$ \\
\hline
\end{tabular}

Note: ${ }^{*} \mathrm{P}<0.05,{ }^{* *} \mathrm{P}<0.01,{ }^{* * *} \mathrm{P}<0.001$

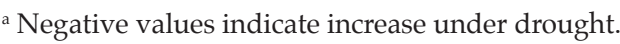

ns - not significant. 
two pairs of trials. A few progenies actually yielded more under drought than with irrigation; we assume this resulted from experimental error.

There were significant differences among progenies in oil / bunch in all trials (data not shown), but effects of drought on oil/bunch were not tested, as most bunch analysis was done during the wet season.

Effects of irrigation/drought and results of the GxE analysis for vegetative growth measurements are given in Table 3 . There were significant differences among progenies for most measurements in most trials. There were also significant effects of drought in most trials, although the average effect was quite small, except for leaf area, which was increased in six trials, by a mean of $8 \%$, and reduced in the other trial. With increased leaf area and reduced petiole cross-section area in most trials, the ratio of leaf area to leaf dry weight was increased by an average of
16\%. GxE interactions were significant for some measurements.

Table 4 shows correlations between irrigated and unirrigated progeny means. The correlations for FFB yield were low, and only statistically significant in two pairs of trials. Figure 1 shows yields for one pair of trials. In some progenies, there was no loss of yield caused by drought, while in the worst affected progeny the loss was nearly $10 \mathrm{t} \mathrm{ha}^{-1}$. In most trials, there were some progenies with negligible yield loss, and others for which the loss exceeded 30\%, with the most susceptible suffering a $50 \%$ loss (Table 2). In most trials, for characteristics other than FFB yield the correlations were generally positive and often highly significant.

By combining all trials, a males $x$ females analysis of parental effects for progenies linked through common parents was possible for the loss of yield caused by drought. The differences between

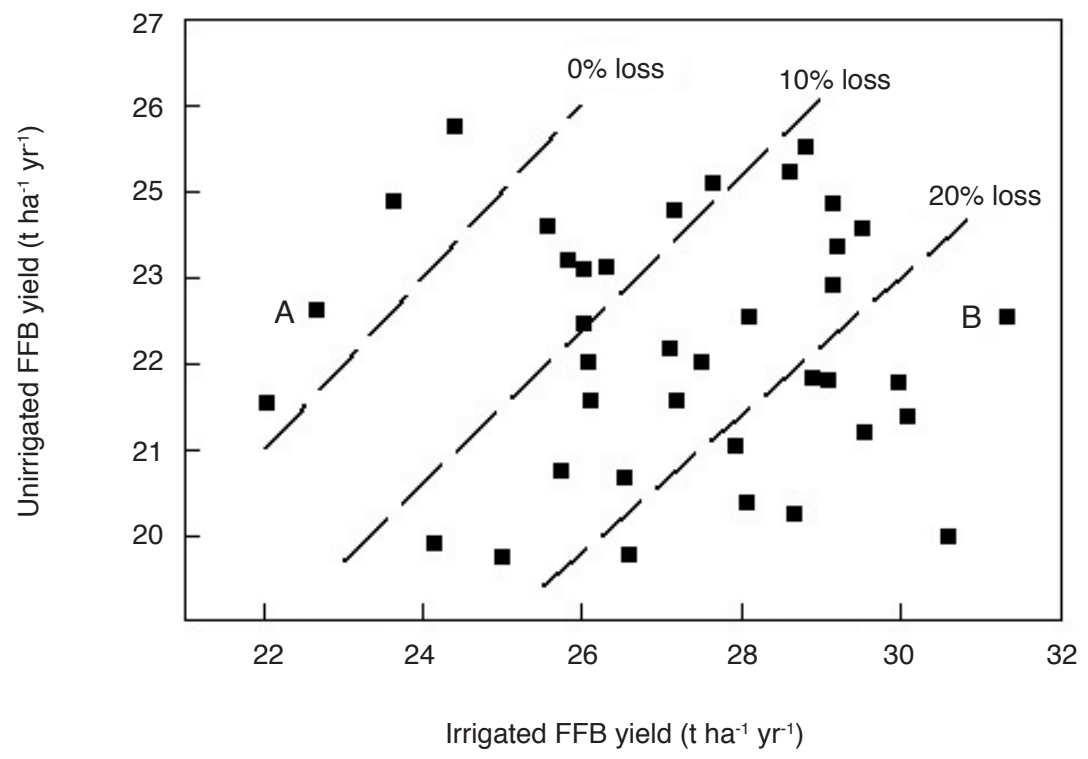

Figure 1. Fresh fruit bunch (FFB) yield with and without irrigation (UPT05/1 and 05/2). Points represent individual progenies. Dotted lines indicate expected unirrigated yields with no loss, $10 \%$ loss and $20 \%$ loss caused by drought. Progenies marked A and B are discussed further in the text.

TABLE 4. CORRELATIONS BETWEEN PROGENY MEANS IN IRRIGATED AND UNIRRIGATED TRIALS

\begin{tabular}{|c|c|c|c|c|c|c|c|}
\hline \multirow{2}{*}{ Trials } & \multirow{2}{*}{$\begin{array}{l}\text { No. of } \\
\text { crosses }\end{array}$} & \multicolumn{6}{|c|}{ Correlations } \\
\hline & & FFB yield & Bunch No. & Bunch wt & Oil/bunch & Height & Petiole $X^{a}$ \\
\hline UPT05/1i and 05/2 & 39 & 0.029 & $0.743^{* * *}$ & $0.771^{* * *}$ & $0.758^{\star * *}$ & $0.865^{\star \star *}$ & $0.527^{\star * *}$ \\
\hline UPT05/3i and 05/4 & 30 & 0.152 & $0.436^{*}$ & $0.735^{\star * *}$ & $0.500^{* *}$ & $0.738^{* * *}$ & $0.711^{* * *}$ \\
\hline UPT06/3i and 06/4 & 13 & 0.312 & 0.443 & $0.828^{\star \star \star}$ & $0.681^{*}$ & 0.535 & $0.690^{*}$ \\
\hline UPT06/5i and 06/6 & 29 & $0.428^{*}$ & $0.748^{* * *}$ & $0.895^{\star * *}$ & $0.645^{\star * *}$ & $0.866^{* * *}$ & $0.593^{* * *}$ \\
\hline UPT07 / $2 \mathrm{i}$ and 07 / 4 & 18 & -0.040 & 0.376 & 0.257 & $0.807^{* * *}$ & 0.303 & $0.575^{\star}$ \\
\hline UPT10/1i and 10/3 & 11 & 0.467 & 0.473 & $0.670^{*}$ & -0.095 & $0.643^{*}$ & -0.198 \\
\hline UPT10/2i and 10/4 & 24 & $0.449^{*}$ & $0.609^{* *}$ & 0.157 & $0.449^{*}$ & $0.709^{* * *}$ & 0.202 \\
\hline
\end{tabular}

Note: ${ }^{*} \mathrm{P}<0.05,{ }^{* *} \mathrm{P}<0.01,{ }^{* * *} \mathrm{P}<0.001$

a Petiole XS - petiole cross-section area.

FFB - fresh fruit bunch. 
TABLE 5. LOSS OF YIELD CAUSED BY DROUGHT FOR SOME Pisifera PARENTS AND THEIR OFFSPRING

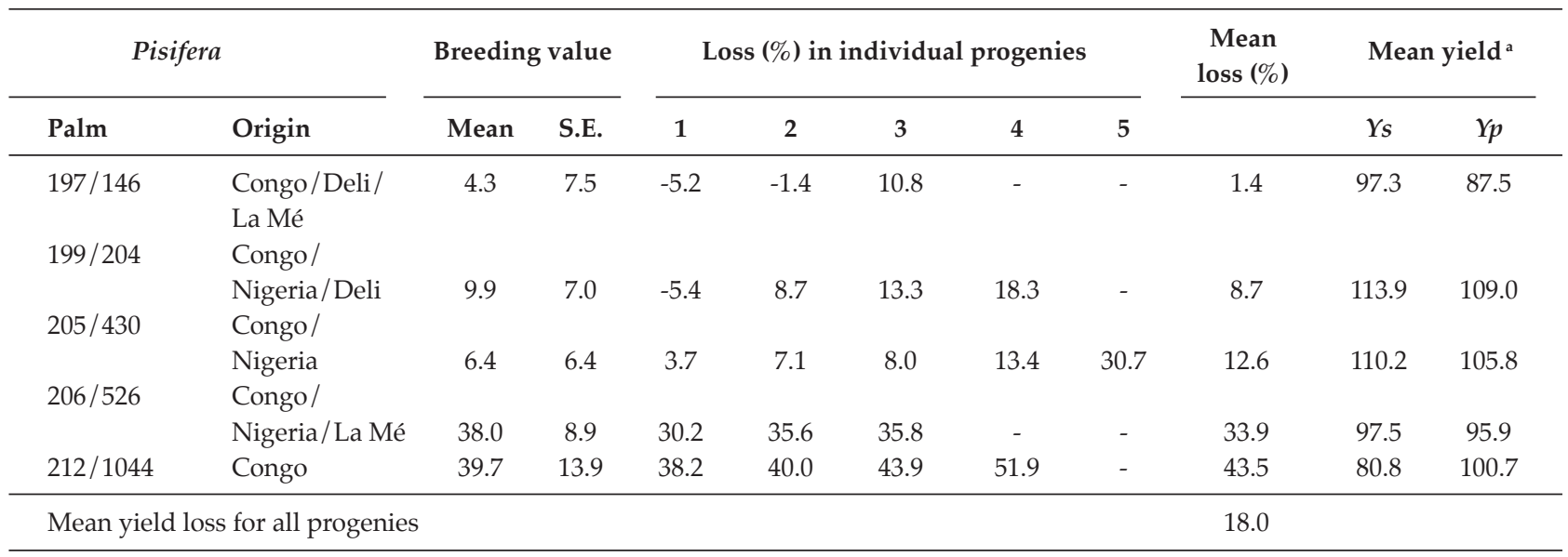

Note: ${ }^{a}$ Fresh fruit bunch yield as \% trial mean.

S.E. - standard deviation.

$Y p$ - yield with irrigation.

$Y_{S}$ - yield without irrigation.

pisifera parents were not statistically significant $(P=0.08)$, but the range of values for individual pisifera palms was large, as shown by the examples in Table 5. Differences among dura parents were not statistically significant.

In addition to a small loss caused by drought, we also need high yield potential $(Y p)$. Table 5 shows that pisiferas 199/204 and 205/430 both met this requirement, with their progenies showing below average drought losses, and $Y p$ averaging respectively $109 \%$ and $106 \%$ above the irrigated trial mean. In contrast, although the progenies from $197 / 146$ had very small drought losses $Y p$ averaged $12 \%$ below the trial mean.
The actual loss of yield caused by drought is compared with predictions from the parental breeding values for individual progenies in Figure 2. The correlation was highly significant $(r=0.877$, 120 d.f.).

Table 6 shows that the effect of drought was negatively correlated with unirrigated yield in all trials; that is, the greater the unirrigated yield, the smaller the effect of drought. Correlations were also calculated between the effect of drought and measurements made under irrigation, to try to identify an indirect method of selection for drought tolerance. Table 6 shows that in some trials irrigated yield and bunch number were positively correlated

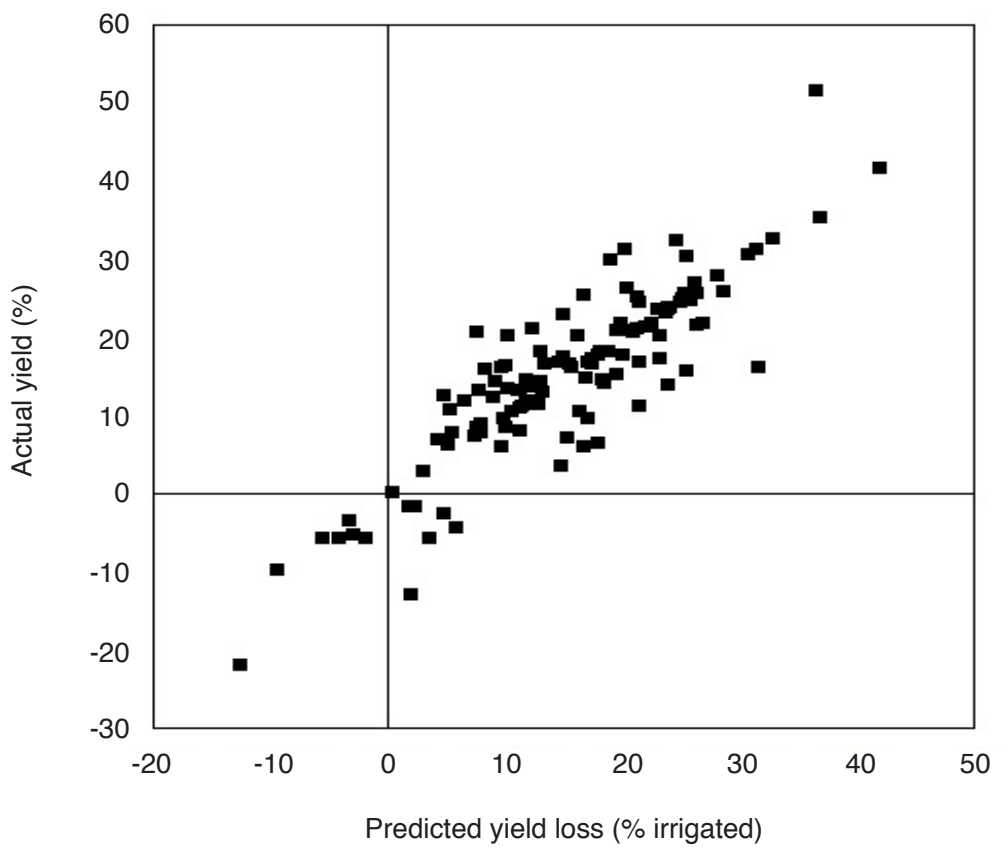

Figure 2. Comparison of actual fresh fruit bunch (FFB) yield loss due to drought with predictions based on least square means for parents (negative values indicate higher yield under drought). 
TABLE 6. CORRELATIONS OF DROUGHT EFFECT ${ }^{a}$ WITH FRESH FRUIT BUNCH (FFB) YIELD, YIELD COMPONENTS, GROWTH MEASUREMENTS AND STOMATAL CONDUCTIVITY

\begin{tabular}{|c|c|c|c|c|c|c|c|}
\hline Correlation with & $05 / 1 \& 2$ & $05 / 3 \& 4$ & $06 / 3 \& 4$ & $06 / 5 \& 6$ & $07 / 2 \& 4$ & $10 / 1 \& 3$ & $10 / 2 \& 4$ \\
\hline Unirrigated yield $\left(Y_{S}\right)$ & $-0.617^{* * *}$ & $-0.621^{* * *}$ & $-0.898^{* * *}$ & $-0.782^{* * *}$ & $-0.650^{* *}$ & $-0.748^{* *}$ & $-0.811^{* * *}$ \\
\hline Irrigated yield $(Y p)$ & $0.763^{* * *}$ & $0.668^{* * *}$ & 0.136 & 0.225 & $0.767^{* * *}$ & 0.236 & 0.082 \\
\hline Irrigated bunch No. & $0.366^{*}$ & $0.643^{* * *}$ & 0.180 & 0.260 & $0.702^{* *}$ & 0.184 & 0.005 \\
\hline Irrigated bunch Wt & 0.235 & 0.017 & -0.093 & -0.185 & -0.009 & 0.305 & 0.112 \\
\hline Irrigated height & 0.179 & -0.121 & -0.008 & 0.050 & $-0.569^{*}$ & 0.601 & 0.092 \\
\hline Irrigated leaf area & 0.091 & 0.334 & 0.010 & 0.067 & -0.075 & 0.374 & 0.331 \\
\hline Irrigated petiole XS & $0.462^{* *}$ & 0.121 & 0.298 & 0.039 & -0.065 & 0.283 & 0.115 \\
\hline Irrigated rachis length & $0.376^{*}$ & 0.269 & 0.371 & -0.007 & 0.015 & 0.211 & 0.467 \\
\hline Irrig. leaf area/leaf wt & $-0.431^{* *}$ & 0.288 & -0.324 & -0.064 & 0.026 & 0.103 & 0.231 \\
\hline Irrigated conductivity & $-0.322^{*}$ & - & 0.232 & - & - & - & - \\
\hline Degrees of freedom & 37 & 28 & 11 & 27 & 16 & 9 & 22 \\
\hline
\end{tabular}

Note: ${ }^{a}$ Reduction in FFB yield under drought, as percentage of irrigated yield: $\left(Y_{S}-Y_{p}\right) / Y_{p}$.

* $\mathrm{P}<0.05,{ }^{* *} \mathrm{P}<0.01,{ }^{* * *} \mathrm{P}<0.001$.

with the loss caused by drought, but there were no consistent correlations with other measurements.

Stomatal conductance was measured in trials UPT05/1i and 05/2 in 2013. Differences between progenies and trials were significant; the GxE interaction was not significant, but the correlation between irrigated and unirrigated means was low $(r=0.19,37$ d.f). There was a significant negative correlation between conductance under irrigation and FFB yield loss due to drought (Table 6); that is, the greater the conductance with irrigation, the smaller the yield loss when irrigation was withheld. Measurements were also made in the irrigated plots of the small trial UPT06/3i, but there the correlation with yield loss was positive, and not significant (Table 6).

\section{DISCUSSION}

Overall, the average FFB yield loss from drought in these pairs of trials was $18 \%$ (Table 2). In irrigation trials, Palat et al. (2008) recorded losses of 25\%-35\%. The losses here are estimated less reliably, from a comparison between trials, than from replicated irrigation trials, but average annual water deficit was slightly larger for these trials than for the years when the trials of Palat et al. (2008) were done. The palms in our trials were younger than those studied by Palat et al., but our experience suggests that young palms are more susceptible to drought than older palms, not less. There might have been soil differences between trials, but it appears that, on average, these progenies were less drought susceptible than the planting material used by Palat et al. (2008).

Oil/bunch was not recorded during the dry season, so we have no indication of the effect of drought on oil yield; this will be investigated in future work. Mill oil extraction tends to be lower during the dry season (Univanich, unpublished), but Nouy et al. (1999) found little difference in oil/ bunch for the same progenies in West Africa and Sumatra.

Considering individual pairs of trials, it is clear that irrigated yields are a poor indicator of yields under drought; correlations were low, and in some trials the GxE interaction was significant. One possible explanation of the low correlation between trials is errors in planting; Corley (2005) showed that illegitimacy was common in older oil palm trials in other programmes, so this possibility should always be considered. In this study, there were highly significant correlations between progeny means in pairs of trials for characters less affected by drought (bunch weight, wet season oil/ bunch, height, petiole cross-section). In some pairs, some of these correlations were low, but overall the positive correlations indicate that the trials were planted correctly. Thus, the poor correlations and GxE interactions for FFB yield imply that progenies differ in their response to drought. Although we did not find statistically significant differences between parents in yield loss under drought, the range of values was large, and some parents gave consistent results, as shown in Table 5. The predictions for individual progenies based on breeding values for the parents were highly correlated with actual yield loss (Figure 2).

There were positive correlations between irrigated and unirrigated trials for bunch weight and bunch number, so selection for these yield components might be relatively unaffected by drought, but weight and number are usually negatively correlated (Corley and Tinker, 2016), and it is their product, FFB yield, which is the important character in progeny testing.

Table 6 shows that the effect of drought on yield was smallest in progenies with the greatest yields in unirrigated conditions; the correlations were all 
negative (Figure 3). Thus selection under drought will, unsurprisingly, tend to give material which is drought tolerant. Perhaps more importantly, in some trials the effect of drought was positively correlated with yield under irrigation; that is, the highest yielding progenies under irrigation also tended to be drought susceptible (Figure 4). Thus, selection for yield under non-droughted conditions may not be effective in developing drought tolerant material. Plant breeders often assume that a high-yielding variety will perform well under all conditions, so that selection under optimal conditions is all that is necessary, but Blum (2005) pointed out that negative relationships between yield potential and drought tolerance are not unusual.

The distinction between yield potential and drought tolerance is illustrated by comparing the progenies marked A and B in Figure 1. They have similar unirrigated FFB yields of about $23.5 \mathrm{t} \mathrm{ha}^{-1}$ $\mathrm{yr}^{-1}$, but progeny A is highly drought tolerant, giving much the same yield with and without irrigation, while progeny $B$ is very drought susceptible, but has a much higher yield potential than A. In selecting parents for seed production, breeders will aim to

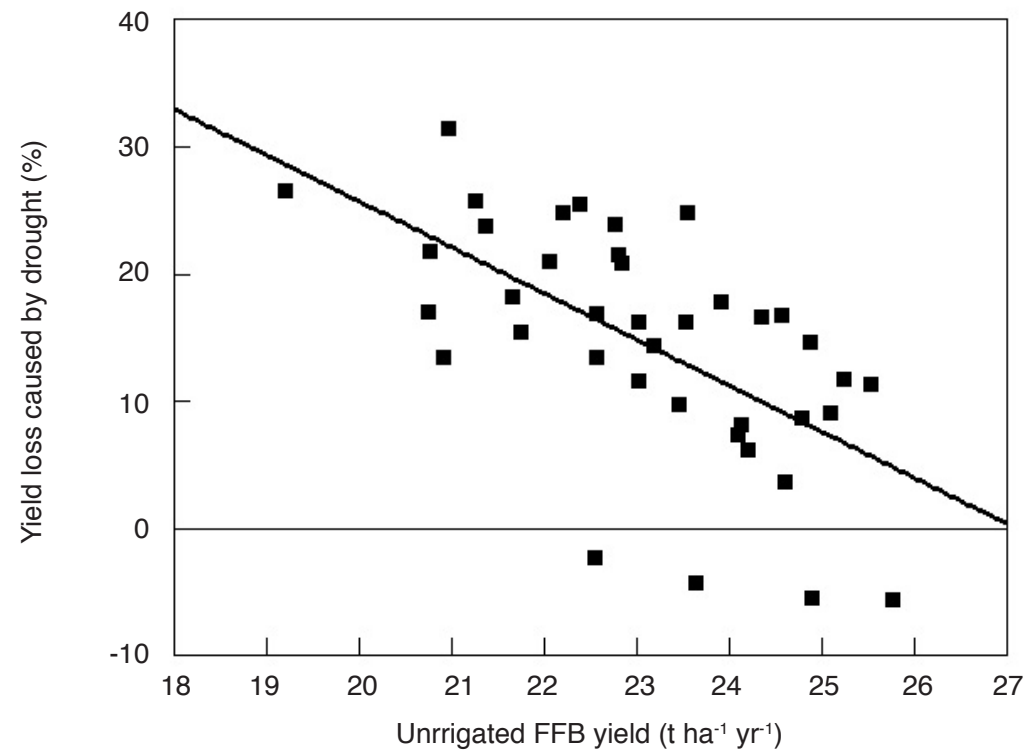

Note: FFB - Fresh fruit bunch.

Figure 3. Relationship between yield loss caused by drought and unirrigated yield (Trials UPT05/1i and 05/2) (negative values indicate higher yield under drought).

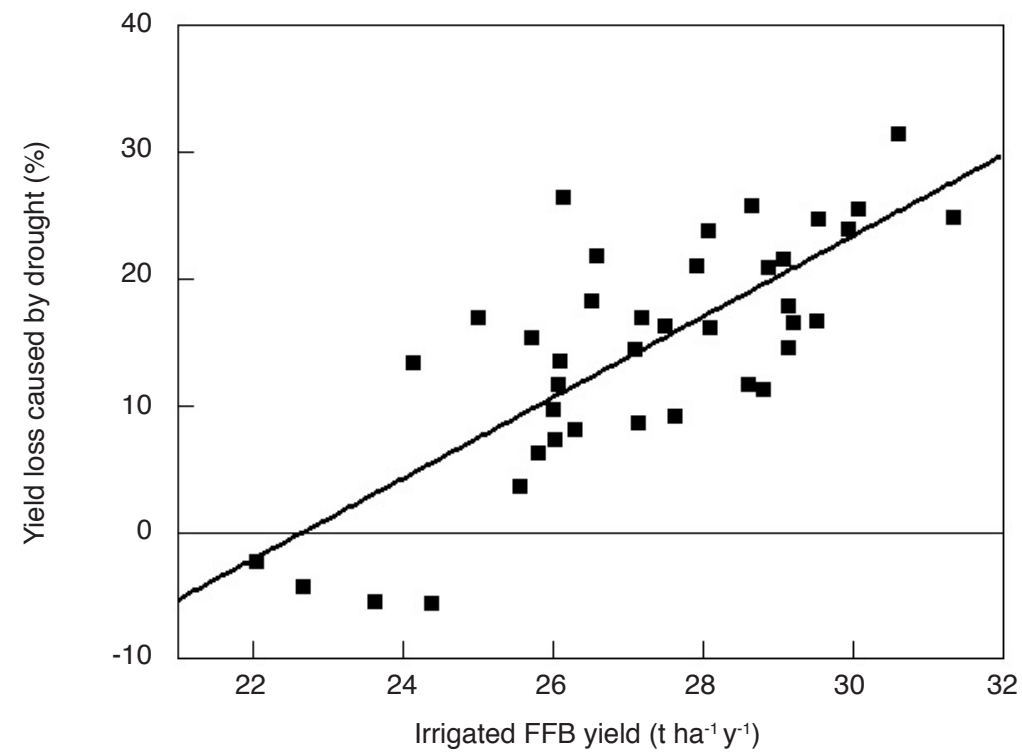

Note: FFB - Fresh fruit bunch.

Figure 4. Relationship between yield loss caused by drought and irrigated yield (Trials UPT05/1i and 05/2) (negative values indicate higher yield under drought). 
combine drought tolerance with high yield potential. Two of the pisiferas in Table 5 appear to meet this requirement, with relatively small drought losses, and $Y p$ above the trial mean.

As selection for yield under irrigation does not give drought tolerant material, we looked at the possibility of indirect selection for drought tolerance, using other measurements made under irrigation. Table 6 shows correlations between drought loss and other measurements. The significant correlations with bunch number are probably simply a reflection of the fact that variation in FFB yield between progenies is predominantly due to variation in bunch number, rather than mean bunch weight (data not shown). High yielding progenies tend to be drought susceptible, as noted above, so high bunch number progenies also tend to be susceptible. Apart from bunch number, there were no consistent correlations between irrigated measurements and drought loss.

Smith (1993) found a positive correlation between dry season stomatal conductance and yield in the Democratic Republic of Congo, and considered that stomatal conductance might be an indicator of the efficiency of the root system in extracting water from the soil. Our preliminary finding in Trials UPT05/1i and 05/2 that larger conductance under irrigation is associated with smaller yield loss under drought can be interpreted in the same way. In contrast to Smith's results, though, we found no correlation between conductance in the unirrigated trial and unirrigated yield $(r=-0.071$, 37 d.f.) or yield loss $(r=0.005)$. Results from the small trials UPT06/3i and 06/4 also did not show a negative relation between irrigated conductance and yield loss. Clearly more measurements of stomatal conductance in other trials are needed before any conclusions can be drawn. Nodichao et al. (2011) emphasised the importance of root density for water uptake, so it would be worth investigating root density in these trials. The trials also offer the possibility of identifying molecular markers for drought tolerance.

\section{CONCLUSION}

As the oil palm industry expands into droughtprone regions, drought tolerant planting material will be needed. We conclude from this work that selection needs to be done under the conditions (in terms of drought) in which the material will be planted. Yield in the absence of drought is not a good indicator of yield with a regular dry season, and vice versa. We have identified some pisifera parents that appear to transmit drought tolerance consistently to their offspring, which will be valuable both for seed production and for further breeding. We have not found a method for indirect selection for drought tolerance under non-droughted conditions, but more work on stomatal conductance appears justified.

\section{ACKNOWLEDGEMENT}

We are grateful to the Board of Directors of Univanich Palm Oil PCL for permission to publish, and to the staff of the Univanich Oil Palm Research Centre for recording of the trials.

\section{REFERENCES}

BLUM, A (2005). Drought resistance, water use efficiency and yield potential - are they compatible, dissonant or mutually exclusive? Aust. J. Agric. Res., 56: 1159-1168.

BLAAK, G; SPARNAAIJ, L D and MENENDEZ, $\mathrm{T}$ (1963). Breeding and inheritance in the oil palm (Elaeis guineensis Jacq.). Part II. Methods of bunch quality analysis. J W Afr Inst Oil Palm Res., 4: 146-155.

BREURE, C J and VERDOOREN, L R (1995). Guidelines for testing and selecting parent palms in oil palm. Practical aspects and statistical methods. ASD Oil Palm Papers, 9: 1-101.

CORLEY, R H V; HARDON, J J and TAN, G Y (1971). Analysis of growth of the oil palm (Elaeis guineensis Jacq.). 1. Estimation of growth parameters and application in breeding. Euphytica, 20: 307-315.

CORLEY, R H V and HONG, T K (1982). Irrigation of oil palms in Malaysia. The Oil Palm in Agriculture in the Eighties (Pushparajah, E and Chew, P S eds.). Vol. 2. Incorp. Soc. Planters, Kuala Lumpur. p. 343-346.

CORLEY, R H V (2005). Illegitimacy in oil palm breeding - a review. J. Oil Palm Res. Vol. 17: 64-69.

CORLEY, R H V (2009). How much palm oil do we need? Environ Sci Policy, 12: 134-139.

CORLEY, R H V and TINKER, P B (2016). The Oil Palm. Wiley Blackwell, Oxford.

CORNAIRE, B; HOUSSOU, $\mathrm{M}$ and MEUNIER, J (1989). Breeding for drought resistance in the oil palm. 2. Kinetics of stomatal opening and protoplasmic resistance. Paper presented at the International Conference Palms and Palm Products. Nigerian Inst. Oil Palm Res., Benin City, 21-25 November 1989.

CORNAIRE, B: DANIEL, C; ZUILY-FODIL, Y and LAMADE, E (1994). Oil palm performance under 
water stress. Background to the problem, first results and research approaches. Oléagineux, 49: 1-11.

DA SILVA, V; ROUAULT, O; KPAVODE, $\mathrm{H}$ and PHAM THI, A (1984). Effect of drought on Ribulose bisphosphate carboxylase/oxygenase activity in soya-bean and oil-palm leaf tissues. Advances in Photosynthesis Research (Sybesma, C ed.). Martinus Nijhoff/Dr W.Junk, The Hague, Vol IV. p. 411-413.

DESMAREST, J (1967). Essai d'irrigation sur jeune palmeraie industrielle. Oléagineux, 22: 441-447.

HOUSSOU, M; OMORE, A and MEUNIER, J (1989). Breeding for drought resistance in the oil palm 1. Variability of some crosses for their productivity and their mortality. Paper presented at the International Conference Palms and Palm Products. Nigerian Inst. Oil Palm Res., Benin City, 21-25 November 1989.

LAMADE, E; SETIYO, I E; MULUCK, C and HAKIM, M (1998). Physiological study of three contrasting clones in Lampung (Indonesia) under drought in 1997. Paper presented at the Interbational Conference on Developments in oil palm plantation industry for the $21^{\text {st }}$ century, Bali, Indonesia, 21-22 September 1998.

LEGROS, S; MIALET-SERRA, I; CLEMENT-VIDAL, A; CALIMAN, J P; SIREGAR, F A; FABRE, D and DINGKUHN, M (2009). Role of transitory carbon reserves during adjustment to climate variability and source-sink imbalances in oil palm (Elaeis guineensis). Tree Physiol, 29: 1199-1211.

MAILLARD, G; DANIEL, C and OCHS, R (1974). Analyse des effets de la sécheresse sur le palmier à huile. Oléagineux, 29: 397-404.

NODICHAO, L; CHOPART, J L; ROUPSARD, O; VAUCLIN, M; AKÉ, S and JOURDAN, C (2011). Genotypic variability of oil palm root system distribution in the field. Consequences for water uptake. Pl E Soil, 341: 505-520.

NOUY, B; BAUDOUIN, L; DJEGUI, N and OMORE, A (1999). Oil palm under limiting water supply conditions. Plantations, Recherche, Développement, 6: 31-45.

PALAT, T; CHAYAWAT, N; CLENDON, J H and CORLEY, R H V (2008). A review of 15 years of oil palm irrigation research in Southern Thailand. The Planter, 84: 537-546.

RAO, V; SOH, A C; CORLEY, R H V; LEE, C H; RAJANAIDU, N; TAN, Y P; CHIN, C W; LIM, K C;
TAN, S T; LEE, T P and NGUI, M (1983). A critical reexamination of the method of bunch quality analysis in oil palm breeding. PORIM Occasional Paper No. 9: 1-28.

RIVERA MÉNDEZ, Y D; CHACÓN, L M; BAYONA, C J and ROMERO, H M (2012). Physiological response of oil palm interspecific hybrids (Elaeis oleifera H.B.K. Cortes versus Elaeis guineensis Jacq.) to water deficit. Braz J Pl Physiol, 24: 273-280.

SILVA, P A; OLIVEIRA, I V; RODRIGUES, K C B; COSME, V S; BASTOS, A J R; DETMANN, K S C; CUNHA, R L; FESTUCCI-BUSELLI, R A; DAMATTA, F M and PINHEIRO, H A (2015). Leaf gas exchange and multiple enzymatic and non-enzymatic antioxidant strategies related to drought tolerance in two oil palm hybrids. Trees, 30: 203-214.

SILVA, P A; COSME, V S; RODRIGUES, K C B; DETMANN, K S C; LEAO, F M; CUNHA, R L; FESTUCCI-BUSELLI, R A; DAMATTA, F $\mathrm{M}$ and PINHEIRO, H A (2017). Drought tolerance in two oil palm hybrids as related to adjustments in carbon metabolism and vegetative growth. Acta Physiol Plant, 39: 58.

SMITH, B G (1993). Correlations between vegetative and yield characteristics and photosynthetic rate and stomatal conductance in the oil palm (Elaeis guineensis Jacq.). Elaeis, 5: 12-26.

SURESH, K; MATHUR, R K and KOCHU BABU, M (2008). Screening of oil palm duras for drought tolerance. J Plantation Crops, 36: 270-275.

SURESH, K; NAGAMANI, C; RAMACHANDRUDU, K and MATHUR, R K (2010). Gasexchange characteristics, leaf water potential and chlorophyll a fluorescence in oil palm (Elaeis guineensis Jacq.) seedlings under water stress and recovery. Photosynthetica, 48: 430-436.

SURESH, K; NAGAMANI, C; KANTHA, D L and KUMAR, M K (2012). Changes in photosynthetic activity in five common hybrids of oil palm (Elaeis guineensis Jacq.) seedlings under water deficit. Photosynthetica, 50: 549-556.

VEERAPPAN, P; BILAL, $M$; NAZEEB, $M$ and LOONG, S G (2000). Early performance and potential of semi-clonal DxP progenies. Proc. of the International Planters Conference Plantation Tree Crops in the New Millennium: The Way Ahead (Pushparajah, E ed.). Incorp. Soc. Planters, Kuala Lumpur. p. 117130. 